\title{
Structure Formation in the Heat Treatment of Relatively Reliable 13XФA Steel Oil Pipe
}

\author{
S. V. Belikov ${ }^{a}$, K. I. Sergeeva ${ }^{a}$, I. N. Ashikhmina ${ }^{b}$, and A. I. Stepanov ${ }^{b}$ \\ ${ }^{a}$ Yeltsin Ural Federal University, Yekaterinburg, Russia \\ ${ }^{b}$ OAO Severskii Trubnyi Zavod, Polevskoi, Russia
}

\begin{abstract}
Attention focuses on the structure and properties of 13ХФA steel obtained on quenching from the intercritical temperature range, when ferrite-martensite structure is formed. Thermokinetic diagrams of the decomposition of supercooled austenite in 13XФA steel on cooling from the single-phase region and the intercritical temperature range are plotted.
\end{abstract}

DOI: $10.3103 / \mathrm{S} 0967091213030029$

In recent years, there has been a sharp increase in global demand for pumping and compressor pipe and oil and gas line pipe with improved corrosion resistance, capable of operating at low temperatures in environments where hydrogen sulfide is present. The reliability and durability of high-pressure pipelines depends on the metal quality of the pipe, which must be characterized by the highest possible strength, high ductility, resistance to brittle and ductile failure at constructional and operational temperatures, good plasticity, corrosion resistance, and weldability. The volume of oil and gas pipe required necessitates a focus on plentiful and inexpensive alloying elements and relatively simple production technologies.

Note that increase in the strength of metal is often accompanied by loss of plasticity or durability. In that content, the potential of two-phase ferrite-martensite steel was noted in [1].

In the present work, we consider the decomposition of supercooled austenite in 13ХФA steel on cooling from the single-phase region and the intercritical temperature range. We also establish that ferrite-martensite structure is formed in double quenching (first from the single-phase region and then from the intercritical range).

We consider economically alloyed 13ХФA structural steel obtained by the industrial technology at OAO Severskii Trubnyi Zavod. The chemical composition of the steel is as follows: $0.15 \% \mathrm{C}, 0.50 \% \mathrm{Mn}$, $0.25 \% \mathrm{Si}, 0.52 \% \mathrm{Cr}, 0.05 \% \mathrm{~V}, 0.002 \% \mathrm{Mo}, 0.13 \% \mathrm{Ni}$, $0.20 \% \mathrm{Cu}, 0.005 \% \mathrm{~S}$, and $0.001 \% \mathrm{P}$ (the remainder is $\mathrm{Fe})$. For the metallographic analysis and mechanical tests, the steel is heated in SNOL laboratory furnaces. An Epiphot 200 microscope (magnification 2001000 ) is used for metallographic analysis. The microstructure is photographed using a Nikon digital camera (on the basis of Nis-Elements Basic Research software). The fine structure is studied by means of a Jeol JSM 6490-IV scanning electron microscope, with an attachment for Inca DryCool microanalysis and Inca Feature software. The decomposition kinetics of supercooled austenite in continuous cooling is investigated on a Linseis L78 R.I.T.A. dilatometer, equipped with a Schaevitz HR 100 (MC) inductive longitudinal-motion sensor.

\section{RESULTS}

In selecting the composition and heat-treatment conditions for the two-phase ferrite-martensite steel, as a rule, the basic goal is to prevent pearlite formation and obtain specific proportions of ferrite and the hardening phase (martensite) [1]. To that end, holding temperatures in the intercritical temperature range where $40-60 \%$ austenite is formed are recommended [2]. That ensures the best distribution of structural components, when the carbon concentration declines from the center of the $\gamma$-phase grains to the periphery.

The quantity of austenite required for an optimal distribution of structural components is formed in the range $790-820^{\circ} \mathrm{C}$, according to [3]. That conclusion is based on the dependence of the proportion of austenite decomposition on the temperature in the intercritical range $\left(A_{c 1}=738 \pm 5^{\circ} \mathrm{C}\right.$ and $\left.A_{c 3}=863 \pm 5^{\circ} \mathrm{C}\right)$, as we see in Fig. 1.

The dependence of the austenite content on the temperature of $13 \mathrm{X} \Phi \mathrm{A}$ steel in Fig. 1 is similar to the results for $12 \mathrm{XH} 4 \mathrm{M} \Phi$ and $10 \mathrm{H} 5 \mathrm{M} \Phi$ steel in [4]. The rate of austenite formation in the intercritical temperature range varies, according to [4]. For instance, the quantity of austenite obtained on heating to the same temperature in the intercritical range in parallel experiments with 15 -min holding may differ by $10 \%$. This variation may be attributed to local deviation in the chemical composition from the mean and also to possible differences in the number of points of austenite nucleation in samples both at the interface of the ferrite and cementite plates and within the free ferrite [2]. 


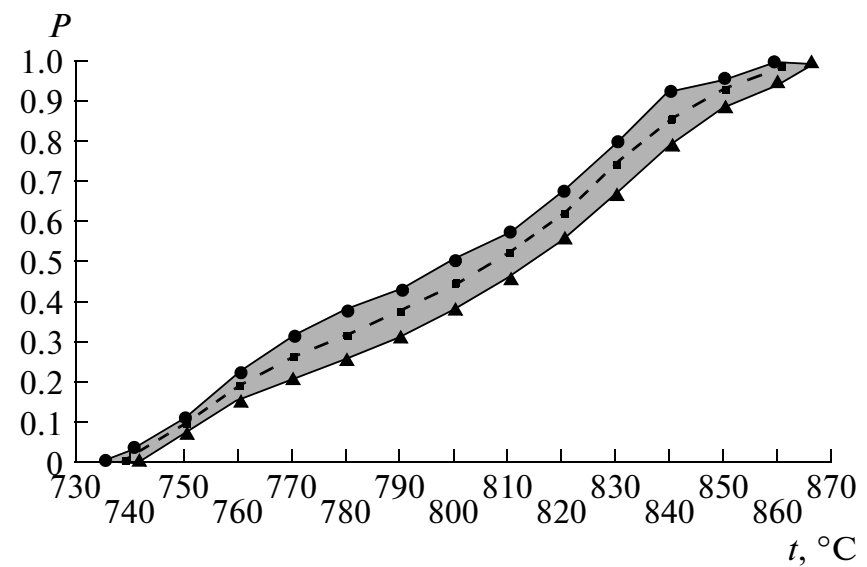

Fig. 1. Temperature dependence of the quantity of austenite in 13ХФA steel [3].

The decomposition of austenite formed in the intercritical temperature range is different from the corresponding process for austenite formed in the single-phase region, as noted in $[1,5]$. That is primarily due to the increased carbon content in the austenite, which should significantly increase its stability. As a result, the austenite component in low-carbon steel is characterized by transformations corresponding to moderate- and high-carbon steel. That permits the production of steel with elevated impact strength and with $\sigma_{0.2} / \sigma_{\mathrm{B}}=0.4-0.5[1]$.

However, contrary to expectation, the stability of the supercooled austenite in 13XФA steel on cooling from the intercritical temperature range is reduced, rather than increased (Fig. 2a) [6]. Such behavior may be explained by the easier nucleation of new phase in an already-existing substrate (the untransformed ferrite) $[1,2]$. Increase in temperature within the intercritical range reduces the stability of the supercooled austenite in the first stage (Fig. 2b). In other words, the temperature at which decomposition begins is raised.

The basic difference between the thermokinetic diagrams is that the temperature-time regions of supercooled-austenite decomposition on cooling from the single-phase region in the first and second stages are not separated by a region of increased stability, since cooling from the intercritical range is associated with clear identification of the first stage of decomposition at cooling rates of $1-40^{\circ} \mathrm{C} / \mathrm{s}$. At the same time, the second stage is reduced on account of the enrichment of austenite with carbon (in comparison with the austenite obtained on cooling completely austenitized steel), and a third stage is clearly distinguishable.
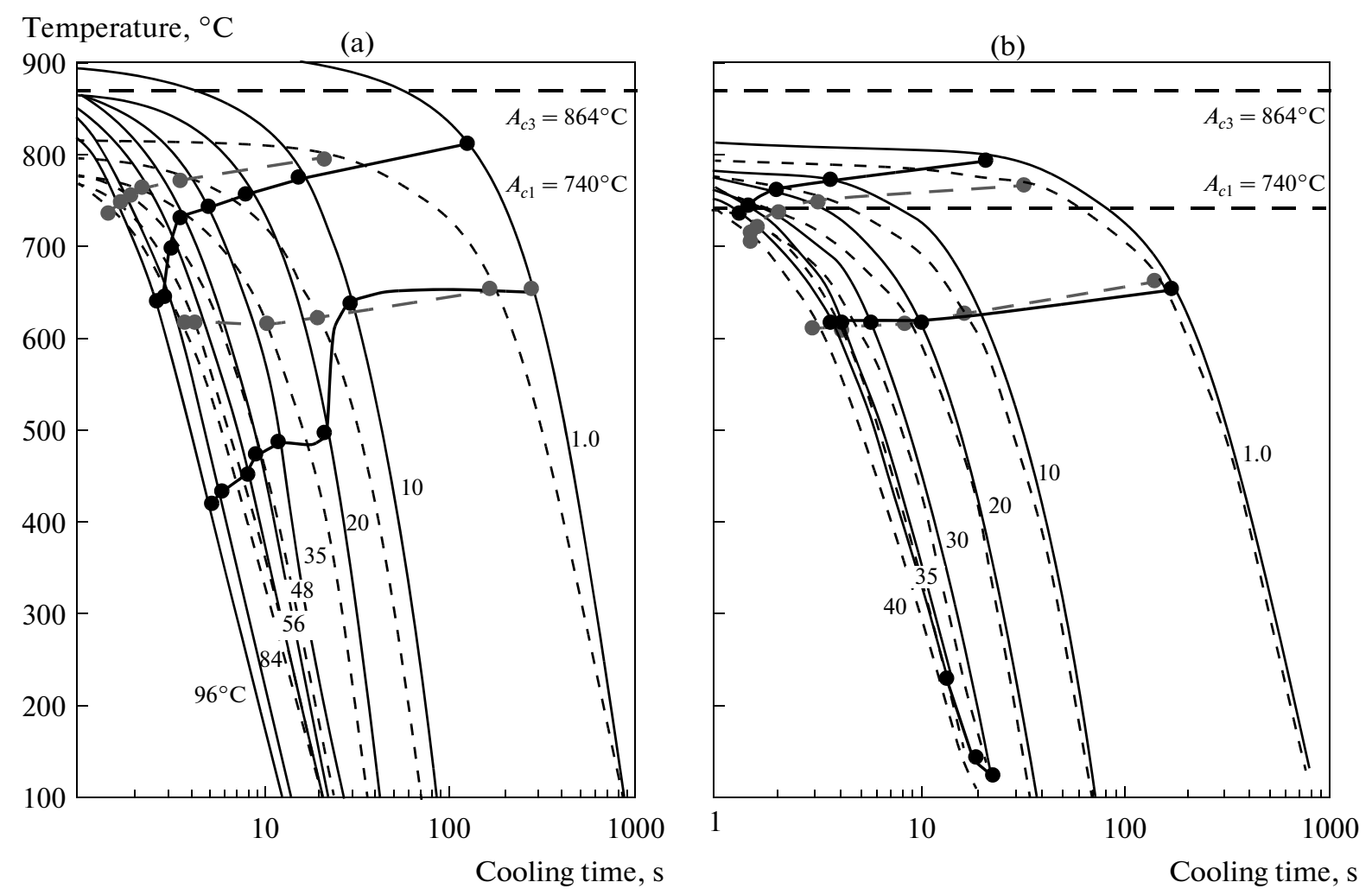

Fig. 2. Thermokinetic diagrams of the decomposition of supercooled austenite in $13 \mathrm{XФA}$ steel on cooling from different austenitization temperatures: (a) $t_{\mathrm{A}}=930$ (continuous curves) and $820^{\circ} \mathrm{C}$ (dashed curves); (b) $t_{\mathrm{A}}=820$ (continuous curves) and $790^{\circ} \mathrm{C}$ (dashed curves). The cooling rate $\left({ }^{\circ} \mathrm{C} / \mathrm{s}\right)$ is noted on the curves. 

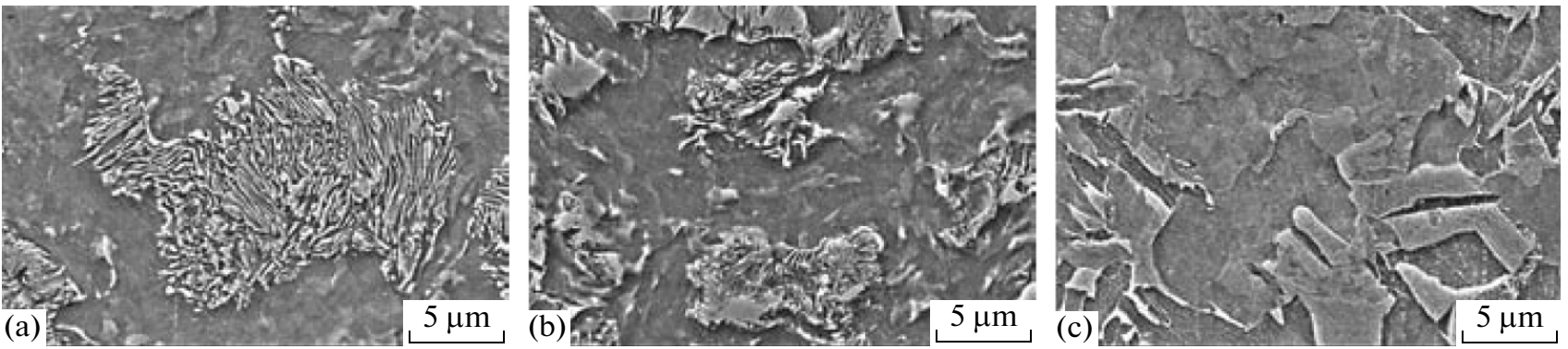

Fig. 3. Microstructure of 13 XФA steel after heating to $930^{\circ} \mathrm{C}$, with subsequent cooling at 1 (a), 10 (b), and $30^{\circ} \mathrm{C} / \mathrm{s}(\mathrm{c})$.

Relatively slow cooling $\left(1.0-10.0^{\circ} \mathrm{C} / \mathrm{s}\right)$ from $t_{\mathrm{A}}=$ $930^{\circ} \mathrm{C}$ leads to the decomposition of austenite with the formation of excess ferrite and pearlite (Fig. 3). The transformation $\gamma \rightarrow \alpha_{\text {exc }}$ begins in the intercritical range, and its starting temperature falls smoothly with increase in the cooling rate from 800 to $775^{\circ} \mathrm{C}$. The final temperature in $\gamma \rightarrow \Pi$ transformation is practically constant $\left(\sim 650^{\circ} \mathrm{C}\right)$, as we see in Fig. $2 \mathrm{a}$.

Analysis of the microstructure shows that the clear pearlite banding in the initial state is practically eliminated. The content of strengthening phase (pearlite) hardly changes (Fig. 4) with increase in cooling rate from 1 to $10^{\circ} \mathrm{C} / \mathrm{s}$ : the corresponding figures are 30 and 40 vol \%. However, the content of highly disperse pearlite increases. The number of colonies in which individual ferrite and cementite plates may be observed falls sharply with increase in cooling rate (Figs. 3a and 3b). As is evident from Fig. 5, on cooling at rates of 1 and $10^{\circ} \mathrm{C}$, most of the supercooled austenite breaks down in the ranges $740-810^{\circ} \mathrm{C}$ and $630-700^{\circ} \mathrm{C}$, respectively. These factors somewhat increase the hardness of the material, from about $H V 170$ to 190.

Increasing the cooling rate to $20-35^{\circ} \mathrm{C} / \mathrm{s}$ facilitates the onset of excess-ferrite deposition. The temperature range of supercooled-austenite decomposition is sharply expanded (by more than $100^{\circ} \mathrm{C}$ ), and the transformation ends at $480-500^{\circ} \mathrm{C}$. According to literature data, there is no significant diffusional redistribution of iron atoms and alloy elements at such temperature, but carbon remains mobile. Therefore, we may assume that the supercooled-austenite decomposition at cooling rates of $20-35^{\circ} \mathrm{C} / \mathrm{s}$ ends with bainite formation. The total content of strengthening structural components increases to $50-65 \%$, while the hardness of the steel increases to $H V$ 220-255. On cooling at $\sim 35-60^{\circ} \mathrm{C} / \mathrm{s}$, the total content of strengthening structural components (bainite) increases to $70-85 \%$, while the hardness of the steel increases to a maximum of $H V 280$.

Cooling from the intercritical range at $30-40^{\circ} \mathrm{C} / \mathrm{s}$ is accompanied by two paths of austenite decomposition: by the diffusional mechanism; and by conversion to martensite. In other words, the decomposition products from the first stage are unavoidable over the whole cross section of the blank on cooling from the intercritical range at practical rates (Fig. 6).

The probability of obtaining two-phase ferritemartensite structures is confirmed for thin plates $(d=$ $3 \mathrm{~mm}$ ), with cooling from the intercritical range at rates greater than $70^{\circ} \mathrm{C} / \mathrm{s}$. The fine structure formed in

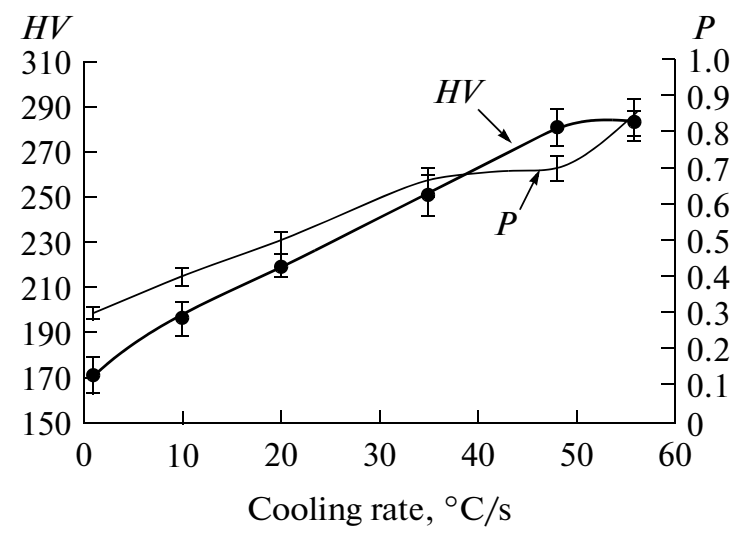

Fig. 4. Variation in hardness $H V$ of $13 X \Phi A$ steel and the content (volume fraction $P$ ) of strengthening phases on cooling from $t_{\text {in }}=930^{\circ} \mathrm{C}$ at various rates.

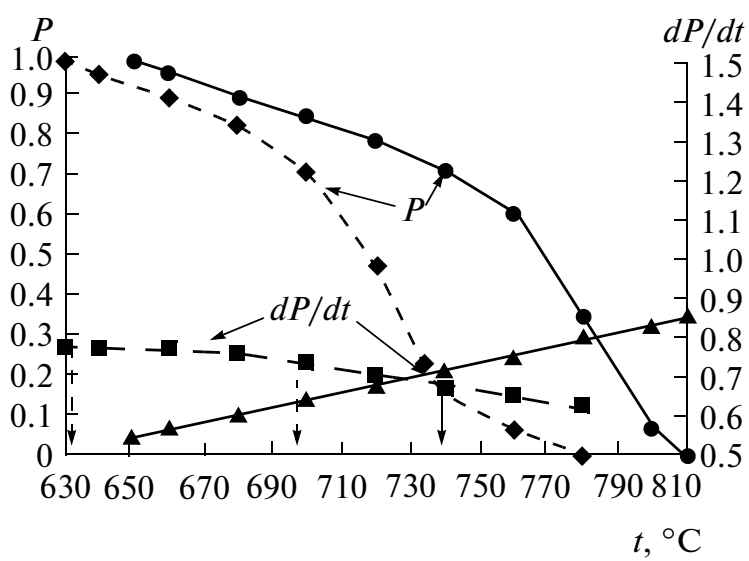

Fig. 5. Variation in the content of decomposition products of supercooled austenite on cooling from $930^{\circ} \mathrm{C}$ at $1{ }^{\circ} \mathrm{C} / \mathrm{s}$ (continuous curves) and $10^{\circ} \mathrm{C} / \mathrm{s}$ (dashed curves). 

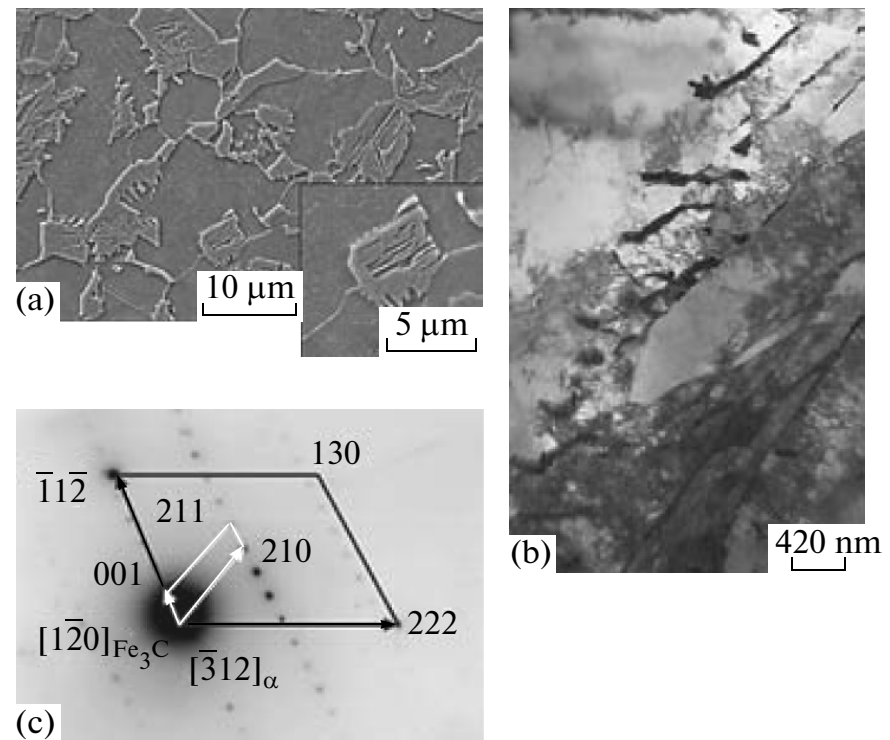

(b)

$420 \mathrm{~nm}$

Fig. 6. Microstructure of $13 \mathrm{XФA}$ steel after cooling from the intercritical range: (a) microstructure; (b) fine structure; (c) microdiffraction pattern.
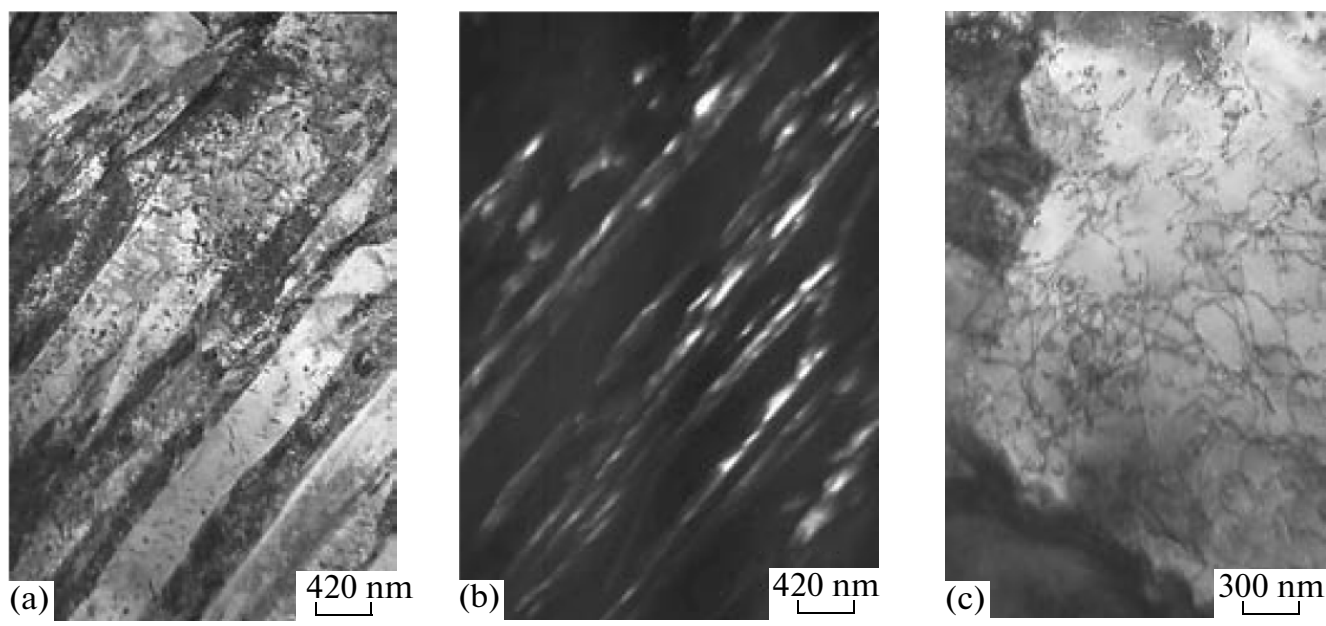

Fig. 7. Fine structure of metal after cooling from $845^{\circ} \mathrm{C}$ : (a) martensite and residual austenite; (b) dark-field image in the [200] reflex; (c) ferrite.

such conditions includes excess ferrite and martensite, with residual austenite (Fig. 7). With increase in temperature in the intercritical range, the austenite content increases. Hence, with accelerate cooling, we must expect increase in the martensite content in thin plates, which increases the hardness of the material (Fig. 8).

Thus, ferrite-martensite structure may only be produced in double quenching (first from the singlephase region and then from the intercritical range) in a thin cross section at large cooling rates or in the surface layers of components in spray quenching. In other cases, the microstructure includes excess ferrite and decomposition products from the first and third stages.

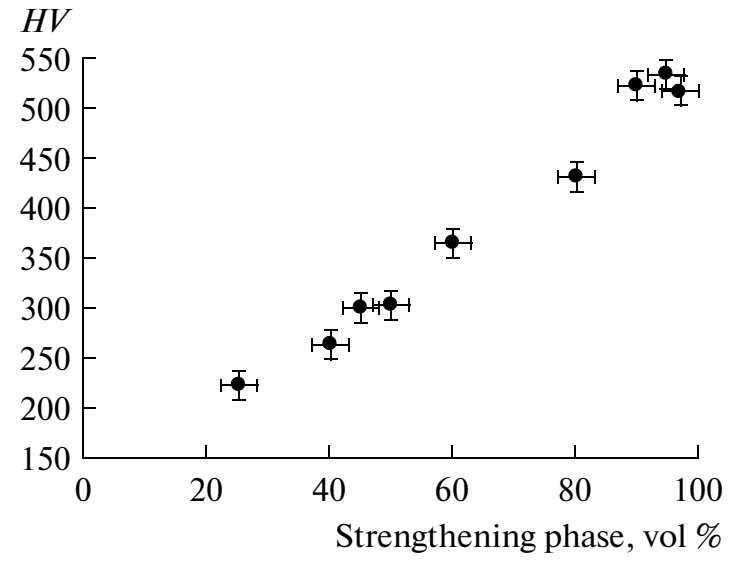

Fig. 8. Dependence of the hardness on the content of strengthening phase. 


\section{CONCLUSIONS}

(1) The critical temperatures for 13ХФA steel have been determined: $A_{c 1}=740 \pm 5^{\circ} \mathrm{C} ; A_{c 3}=864 \pm 5^{\circ} \mathrm{C}$. Having established the variation in the quantity of $\gamma$ phase as a function of the temperature, we may select heat-treatment conditions such as to obtain a specific quantity of decomposition products from supercooled austenite.

(2) We have plotted thermokinetic decomposition diagrams for supercooled-austenite formed in 13XФA steel at $930^{\circ} \mathrm{C}$ (the single-phase $\gamma$ region) and at 820 and $790^{\circ} \mathrm{C}$ (the intercritical range). We have shown that, on cooling from the intercritical range (from 820 and $790^{\circ} \mathrm{C}$ ), the stability of the supercooled austenite in the first stage is reduced, which facilitates the formation of excess ferrite on account of epitaxial growth. Carbon enrichment of the austenite during austenitization in the intercritical range leads to the appearances of regions of elevated stability and a region corresponding to decomposition in the third stage on the thermokinetic diagram, with cooling rates of $30-40^{\circ} \mathrm{C} / \mathrm{s}$.

(3) A two-phase ferrite-martensite structure is formed in a thin cross section at large cooling rates or in the surface layers of components in spray quenching from the intercritical range. At $\sim 30-40^{\circ} \mathrm{C} / \mathrm{s}$, the microstructure formed includes excess ferrite and decomposition products from the first and third stages.

\section{REFERENCES}

1. Golovanenko, S.A. and Fonshtein, N.M., Two-Phase Ferrite-Martensite Steel, Mekhan. Term Obrab. Mater., 1984, no. 11, pp. 25-28.

2. D'yachenko, S.S., Obrazovanie austenita v zhelezouglerodistykh splavakh (Austenite Formation in Ferrocarbon Alloys), Moscow: Metallurgiya, 1982.

3. Belikov, S.V., Sergeeva, K.I., Kornienko, O.Yu., and Musikhin, S.A., Decomposition of Supercooled Austenite in 13ХФA Steel after Heating to the Intercritical Range, Sbornik nauchnykh statei XI mezhdunarodnoi nauchno-tekhnicheskoi ural'skoi shkoly-seminara molodykh uchenykh-metallovedov (Proceedings of Eleventh International Ural Seminar for Young Metallurgists), Yekaterinburg: Izd. UrFU, 2010, pp. 83-85.

4. Schastlivtsev, V.M., Barmina, I.L., Yakovleva, I.L., et al., Formation and Stability of Austenite in LowCarbon Nickel-Molybdenum Steel, Fiz. Met. Metallov., 1983, vol. 55, no. 2, pp. 371-372.

5. Fonshtein, N.M., Heat Treatment to Produce Regulated Ferrite-Martensite Structure of Steel, Mekhan. Term. Obrab. Mater., 1985, no. 8, pp. 46-50.

6. Belikov, S.V., Sergeeva, K.I., Ryzhkov, M.A., et al., Selecting the Conditions of Strengthening Heat Treatment of Highly Reliable Oil and Gas Line Pipe, Trudy XVIII Mezhdunarodnoi nauchno-tekhnicheskoi konferentsii Truby-2010 (Proceedings of Truby-2010: The Thirteenth International Pipe-Technology Conference), Chelyabinsk: OAO RosNITI, 2010, pp. 185191. 